\title{
Early Rise in Serum Concentration of Transferrin Receptor Induced by Recombinant Human Erythropoietin in Very-Low-Birth-Weight Infants
}

\author{
SANNA M. KIVIVUORI, MARKKU HEIKINHEIMO, ANNA-MAIJA TEPPO, AND \\ MARTTI A. SIIMES \\ Children's Hospital [S.M.K., M.H., M.A.S.] and Fourth Department of Medicine [A.-M.T.], \\ University of Helsinki, Helsinki, Finland
}

\section{ABSTRACT}

\begin{abstract}
The serum transferrin receptor (TfR) level reflects iron status and the rate of erythropoiesis. This study was undertaken to assess the role of serum TfR in the iron status and erythropoiesis in very-low-birth-weight infants under conditions in which erythropoiesis is stimulated by large doses of recombinant human erythropoietin (rHuEPO) and oral iron. The first 34 infants were followed from the 3 rd to 11 th wk of life or until discharged. They received iron at a rate of $3 \mathrm{mg} / \mathrm{kg} / \mathrm{d}$. The subsequent 21 infants were given $\mathrm{rHuEPO}(300 \mathrm{U} / \mathrm{kg}$ three times a week s.c.) and iron at a rate of $6 \mathrm{mg} / \mathrm{kg} / \mathrm{d}$ from the 3 rd or 4 th wk of life for a mean of $3.4 \mathrm{wk}$. With this treatment, the need for transfusion was reduced from $1.4 \pm 0.4$ to $0.1 \pm 0.1$ transfusions per infant $(p=0.02)$. The serum TfR concentrations in the rHuEPOtreated infants increased gradually to values several-fold higher than those in the untreated infants. This increase was not related to intrauterine or postnatal growth, protein
\end{abstract}

rHuEPO has been used in the treatment of anemia of prematurity accompanied by a low rate of erythropoiesis and low serum concentrations of erythropoietin (1-8). Several studies have provided evidence for the efficacy of rHuEPO in stimulating erythropoiesis and reducing the requirement for transfusions. For enhanced erythropoiesis, extra iron is needed. However, it is not certain whether this need can be met by any oral dose of iron (5).

Serum TfR is a new measure that reflects iron status and the rate of erythropoiesis (9-14). In healthy adults, it is present in concentrations of approximately $5 \mathrm{mg} / \mathrm{L}$ (10). It becomes elevated soon after signs of iron deficiency appear, and the rise reflects the paucity of available tissue iron. However, the elevated serum TfR level may also be explained by an increase in the erythroid precursor cell mass, and direct effects of erythropoietin

Received July 15, 1993; accepted February 15, 1994.

Correspondence and reprint requests: Sanna-Maria Kivivuori, M.D., Research Laboratory, Children's Hospital, University of Helsinki, Stenbäckinkatu 11, FIN-00290 Helsinki, Finland. intake, or serum albumin concentration. Neither was an association observed between $\mathrm{Hb}$ and $\mathrm{TfR}$ concentration. In the treated infants, the serum ferritin concentration was lower at the $4 \mathrm{th}, 5 \mathrm{th}$, and $7 \mathrm{th}$ wk of life than in the untreated infants. The very-low-birth-weight infants who were given large doses of rHuEPO and iron had a marked rise in serum TfR concentration and a small decline in serum ferritin concentration. These events have been related to iron deficiency. (Pediatr Res 36: 85-89, 1994)

$\quad$ Abbreviations
AGA, appropriate for gestational age
rHuEPO, recombinant human erythropoietin
SGA, small for gestational age
TfR, transferrin receptor
VLBW, very low birth weight

on TfR regulation cannot be excluded. Unlike serum ferritin concentrations, serum TfR concentrations are not influenced by infections or chronic inflammation, which may be of additional advantage $(15,16)$. No studies are available on the role of serum TfR in premature infants.

This study was undertaken to investigate the relationships between the serum TfR concentration and the iron status and rate of erythropoiesis in VLBW infants (birth weight less than $1500 \mathrm{~g}$ ) in whom erythropoiesis is stimulated by large doses of rHuEPO and oral iron.

\section{METHODS}

We studied 55 consecutive VLBW infants. Infants with heart disease, other than patent ductus arteriosus, or with bronchopulmonary dysplasia needing more than $40 \%$ oxygen at $2 \mathrm{wk}$ of age were excluded from the study. The included infants had been weaned from the respirator by 2 wk of age.

The first 34 infants were followed from the 3 rd wk until discharged or up to the 11 th wk. The subsequent 21 
infants were similarly followed, but they were treated with rHuEPO (300 U/kg three times a week s.c.) (Cilag A.G., Schaffhausen, Switzerland). Our aim was to give the rHuEPO treatment during $4 \mathrm{wk}$, but because of early discharges, the average period of treatment was $3.4 \mathrm{wk}$. Treatment was started at the 3 rd or 4 th wk.

The clinical characteristics of the infants are shown in Table 1. The infants were classified as AGA or SGA (birth weights below -2 SD for gestational age) according to Finnish intrauterine growth charts (17). The cord was clamped in all cases within $15 \mathrm{~s}$. Postnatal growth was analyzed by measuring the increment in body weight each week.

Protein intake. Protein intake was quantified at the 4th and 7th wk of life. It was calculated on three nonconsecutive days in each week. Mean values are given for both weeks.

Iron supplementation. Oral iron supplementation was started at $2 \mathrm{wk}$ of age. The dose was gradually increased to $3 \mathrm{mg} / \mathrm{kg} / \mathrm{d}$ by the age of $3 \mathrm{wk}$, which is a routine practice in Finland (18). However, iron at a rate of 6 $\mathrm{mg} / \mathrm{kg} / \mathrm{d}$ divided into three doses was given to the rHuEPO-treated infants during the treatment period to meet the increased iron needs. During the treatment period, the untreated infants received an average of 114 $\mathrm{mg}$ of iron and the treated infants $257 \mathrm{mg}$ of iron. Vitamin (A, B $12, C, D, E$, and folic acid) supplementation was given to all infants.

Transfusion policy. Infants were given red blood cell transfusions, $10 \mathrm{~mL} / \mathrm{kg}$, on the $1 \mathrm{st} \mathrm{d}$ of life if they had any respiratory decompensation. The hematocrit values were maintained above 0.30 . However, infants with symptoms or signs of anemia received transfusions if the hematocrit value was below 0.40 . The estimated blood losses for repetitive laboratory investigations were replaced by red blood cell transfusions until the age of $4 \mathrm{wk}$. Informed consent to the protocol was obtained from the parents. The study was approved by the ethical committees.

Side effects. Blood pressure was measured during the rHuEPO treatment before and 2-8 h after each injection. A granulocyte count was obtained weekly.

Infections. Ten of the 34 untreated infants and three of the 21 treated infants received antibiotics during the study period.

Laboratory investigations. We collected blood samples weekly from the 3rd to 11 th wk of age (a mean of 4.9

Table 1. Clinical characteristics of rHuEPO-treated and untreated infants*

\begin{tabular}{lll}
\hline & Without rHuEPO & With rHuEPO \\
\hline$n$ & 34 & 21 \\
Girls/boys & $16 / 18$ & $9 / 12$ \\
Birth weight $(\mathrm{g})$ & $1186(1114-1258)$ & $1327(1260-1394)$ \\
Gestational age (wk) & $30.9(30.1-31.8)$ & $31.1(30.4-31.9)$ \\
Apgar score at 1 min & $6.1(5.3-6.9)$ & $6.8(6.0-7.6)$ \\
AGA $(n)$ & 17 & 9 \\
SGA $(n)$ & 17 & 12 \\
\hline
\end{tabular}

* Means and $95 \%$ confidence intervals (in parentheses) are given. Of these characteristics, only the birth weights were different $(p=0.008)$. samples per infant) for measurement of blood concentrations of $\mathrm{Hb}$; hematocrit; reticulocyte, white blood cell, and granulocyte counts; and serum concentrations of albumin, ferritin, and TfR. The serum used for measuring the concentration of $\mathrm{TfR}$ was stored at $-20^{\circ} \mathrm{C}$ until assayed.

$\mathrm{Hb}$ concentrations, hematocrit, and white blood cell counts were measured with an automatic counter. Reticulocyte and granulocyte counts were determined microscopically. Serum concentrations of albumin were quantified spectrophotometrically. Serum concentrations of ferritin were measured with an RIA using commercial reagents (Ferritin Ria Kit, Kodak Clinical Diagnostics, Amersham, UK). For measuring the concentration of TfR in serum, we developed a two-step, sandwich-type, time-resolved immunofluorometric assay using two independent mouse MAb obtained from Dr. James D. Cook, Kansas City, KS. (13). Only $10 \mu \mathrm{L}$ of serum are needed for duplicate determinations. Total circulating erythrocyte volume was estimated in $\mathrm{mL}$ according to the following formula: hematocrit $\times$ body weight $(g) \times$ blood volume $(8.5 \%)$. Red cell iron $(\mathrm{mg})$ was calculated from total circulating erythrocyte volume $\times 1.1(19)$.

Statistical analysis. For statistical analyses, the unpaired, two-tailed $t$ test, the Mann-Whitney $U$ test, and simple regression analysis were used as appropriate. A $p$ value of $<0.05$ was considered significant. Means \pm SEM are used unless otherwise mentioned.

\section{RESULTS}

In the rHuEPO-treated infants, the concentration of serum TfR became elevated during the treatment and thereafter returned to the level of the untreated infants within 3 wk (Fig. 1). The concentration remained stable from the 3rd to the 11th wk of life in the VLBW infants without $\mathrm{rHuEPO}$ treatment.

The $\mathrm{Hb}$ concentration was higher in the treated than in the untreated infants at the 4th $(124 \pm 4$ versus $113 \pm 3$ $\mathrm{g} / \mathrm{L}, p=0.02)$, 5th $(116 \pm 3$ versus $103 \pm 3 \mathrm{~g} / \mathrm{L}, p=$ $0.002), 6$ th $(112 \pm 3$ versus $100 \pm 4 \mathrm{~g} / \mathrm{L}, p=0.02)$, and 8 th $(116 \pm 9$ versus $89 \pm 4 \mathrm{~g} / \mathrm{L}, p=0.005)$ wk. Thus, the difference in $\mathrm{Hb}$ concentration was about $10 \%$ during the study period. At the beginning of the study, the mean concentration of $\mathrm{Hb}$ was $140 \pm 4 \mathrm{~g} / \mathrm{L}$ in the treated infants and $134 \pm 4 \mathrm{~g} / \mathrm{L}$ in the others $(p=0.2)$. No associations were observed between the serum concentration of $T f R$ and the blood concentration of $\mathrm{Hb}$ in either the treated or untreated infants.

In the infants receiving $\mathrm{rHuEPO}$, the reticulocyte count was higher than in the untreated infants from the 3 rd until the 5 th wk of life $(4.5 \pm 0.5 \%$ versus $2.5 \pm 0.3 \%$, $p=0.0003$, at the $3 \mathrm{rd} \mathrm{wk} ; 6.8 \pm 0.6 \%$ versus $3.9 \pm 0.6 \%$, $p=0.002$, at the 4 th $\mathrm{wk}$; and $6.7 \pm 0.6 \%$ versus $4.5 \pm$ $0.6 \%, p=0.004$, at the 5th wk of life). There were no associations between the serum concentration of $T f R$ and the reticulocyte count in the treated infants. In the untreated infants, the serum concentration of TfR and the reticulocyte count were associated at the $3 \mathrm{rd}, 4 \mathrm{th}$, and 

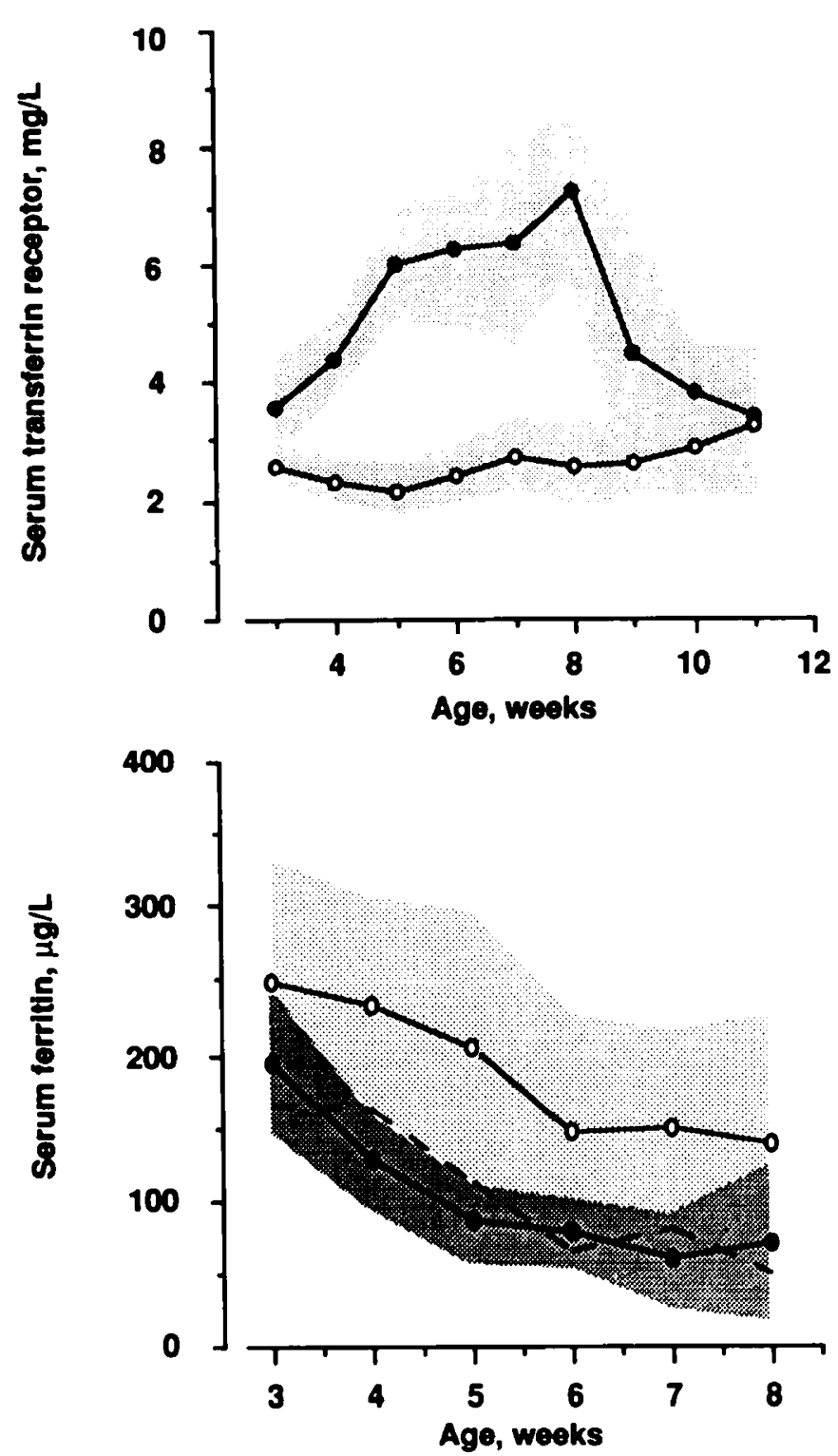

Figure 1. The concentrations of serum TfR (top) and ferritin (bottom) in $21 \mathrm{rHuEPO}-$ treated (filled circles) and 34 untreated (open circles) VLBW infants. The TfR concentration is given between the 3rd and 11th wk of life ( $p \leq 0.01$ at and between the 3rd and 9th wk of life) and the ferritin concentration between the 3rd and 8 th wk of life. Means and $95 \%$ confidence intervals are shown. The broken line in the lower figure indicates the lower limit of the $95 \%$ confidence interval of the untreated infants.

5th wk of life. In Figure 2, we plotted the relationship between the mean TfR concentration and the mean reticulocyte count from the 5th to the 8th wk of life. There was no association between reticulocyte counts and transfused red blood cell volumes.

Total circulating erythrocyte volume was higher in the treated than in the untreated infants from the 3rd until the 7 th wk of life. There was no association between the serum concentration of TfR and total circulating erythrocyte volume in either group. The mean difference in total circulating erythrocyte volumes between the treated and untreated infants during the treatment period was 10.5 $\mathrm{mL} / \mathrm{wk}$. Thus, the rHuEPO-treated infants have pro-

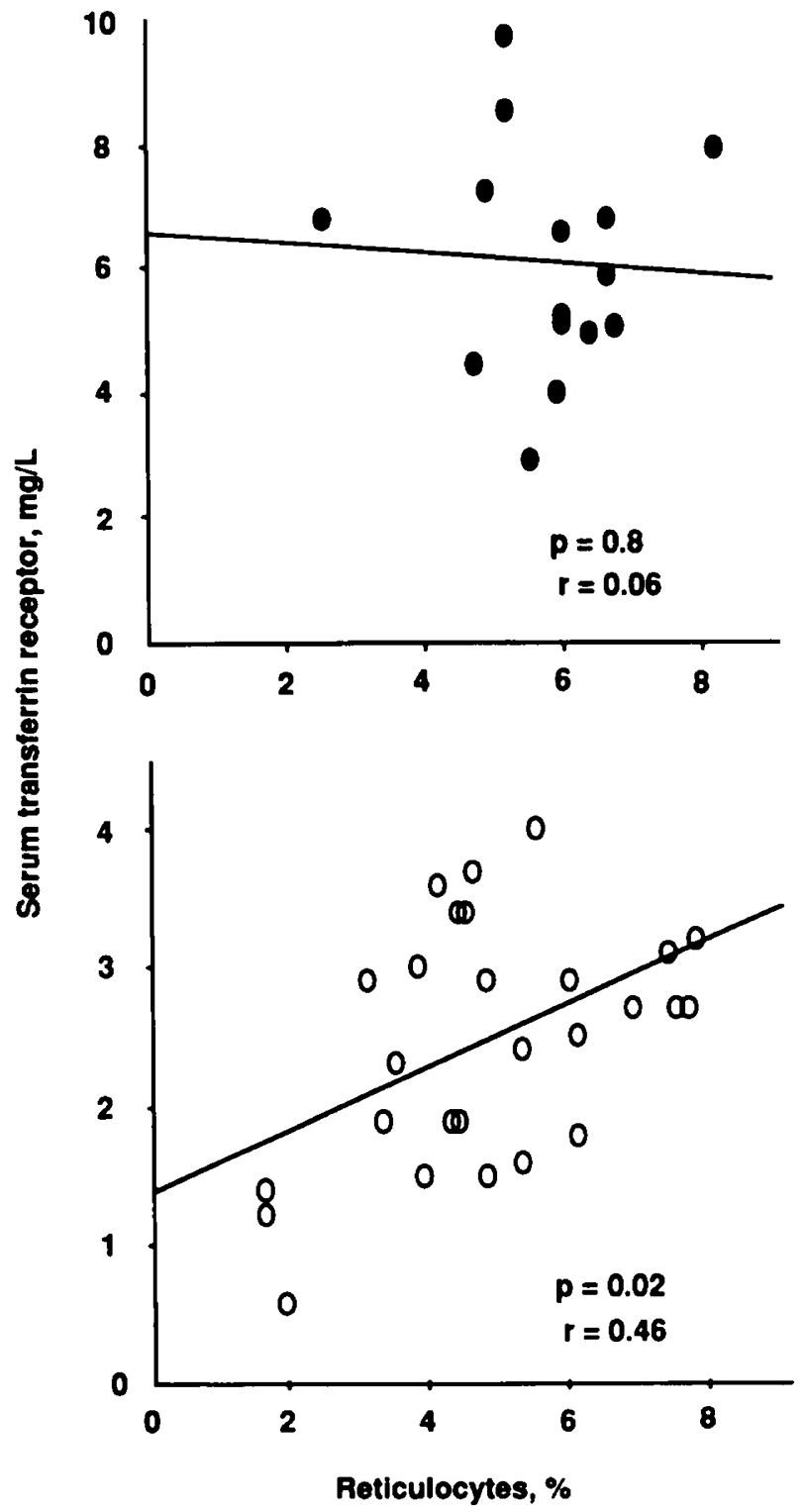

Figure 2. Because the TfR concentration was highest between the 5th and 8th wk of life (Fig. 1), we calculated the relationship between the mean TfR concentration and the mean reticulocyte count from the 5th to the 8th wk of life. Filled circles represent rHuEPO-treated infants and open circles represent untreated infants.

duced $0.8 \mathrm{~mL}$ of red cells per $\mathrm{kg}$ per $\mathrm{d}$ more than the untreated infants.

The serum ferritin concentration was lower in the treated than in the untreated infants at the 4 th, 5 th, and 7 th wk of life (Fig. 1). The serum concentrations of TfR and ferritin correlated inversely at the 4th $(p=0.008, r=$ $0.57)$ and 5th $(p=0.003, r=0.68)$ wk of life in the treated infants. There were no associations between the serum concentrations of TfR and ferritin in the untreated infants. According to Lundström et al. (20), the serum ferritin concentration in low-birth-weight infants receiving iron at a rate of $2 \mathrm{mg} / \mathrm{kg} / \mathrm{d}$ is about $150 \mu \mathrm{g} / \mathrm{L}$ at the age of $1 \mathrm{mo}$ and about $75 \mu \mathrm{g} / \mathrm{L}$ at the age of $2 \mathrm{mo}$.

Need for additional iron in the rHuEPO-treated infants was substantial. The large amount needed is explained by 
the great difference in transfusion volumes and the small difference in $\mathrm{Hb}$ concentration between the treated and untreated infants. Two of the 21 treated infants and 16 of the 34 untreated infants received red blood cell transfusions after the age of $2 \mathrm{wk}$. Thus, the treatment led to a reduction in the mean number of transfusions per infant from $1.4 \pm 0.4$ to $0.1 \pm 0.1(p=0.02)$. Two of the treated infants received a mean of $26 \mathrm{~mL}$ of red blood cells. Thus, the 21 treated infants received a mean of $2.5 \mathrm{~mL}$ of red blood cells per infant. Because the hematocrit of the red blood cell units was about 0.75 , a mean of $1.9 \mathrm{~mL}$ of red blood cells was actually given per treated infant. This amount corresponds to $2.1 \mathrm{mg}$ of red cell iron per infant. In the untreated infants, the estimated total volume of blood transfused varied from 12 to $94 \mathrm{~mL}$ per infant (mean $38 \mathrm{~mL}$ ). Thus, the 34 untreated infants received a mean of $18 \mathrm{~mL}$ of red blood cells per infant. This corresponds to a mean of $14.9 \mathrm{mg}$ of red cell iron per untreated infant. The difference in transfusion volumes was estimated to represent a mean of $12.8 \mathrm{mg}(14.9-2.1 \mathrm{mg})$ of iron per treated infant. The calculated mean red cell iron of the treated infants at the end of the treatment represented $70 \mathrm{mg}$ of iron. The observed $10 \%$ difference in mean $\mathrm{Hb}$ concentration between the treated and untreated infants amounts to $7 \mathrm{mg}$ of iron per treated infant. Accordingly, the mean calculated need for iron to compensate for the difference in transfusion volumes (12.8 $\mathrm{mg}$ ) and in $\mathrm{Hb}$ concentrations $(7 \mathrm{mg}$ ) was $19.8 \mathrm{mg}$.

The treated infants received iron at a rate of $6 \mathrm{mg} / \mathrm{kg} / \mathrm{d}$ during the rHuEPO treatment period and thereafter at a rate of $3 \mathrm{mg} / \mathrm{kg} / \mathrm{d}$, and the untreated infants received iron at a rate of $3 \mathrm{mg} / \mathrm{kg} / \mathrm{d}$ during the whole study period. The difference was approximately $143 \mathrm{mg}$ of iron per infant during the treatment period. Thus, the absorption of extra iron should be at least $14 \%$ of the orally administered iron $(19.8 \mathrm{mg} / 143 \mathrm{mg}=13.8 \%)$.

The serum concentrations of TfR in the AGA and SGA infants were similar. For instance, during the period of rHuEPO treatment, the mean values in the treated infants were $4.9 \pm 0.4 \mathrm{mg} / \mathrm{L}$ in the AGA group and $4.9 \pm 0.5$ $\mathrm{mg} / \mathrm{L}$ in the SGA group, and the mean values in the untreated infants were $2.2 \pm 0.2 \mathrm{mg} / \mathrm{L}$ in the AGA group and $2.4 \pm 0.2 \mathrm{mg} / \mathrm{L}$ in the SGA group. Furthermore, we observed no association between the serum concentration of TfR and the individual rate of postnatal growth in either the treated or the untreated infants, nor did the treated and untreated infants differ in postnatal growth.

Protein intake at the 4th wk of life was $2.4 \pm 0.1$ and 2.3 $\pm 0.1 \mathrm{~g} / \mathrm{kg} / \mathrm{d}$, and at the 7 th wk of life it was $2.7 \pm 0.2$ and $2.7 \pm 0.2 \mathrm{~g} / \mathrm{kg} / \mathrm{d}$ in the treated and untreated infants, respectively $(p>0.05)$. There were no associations between the serum TfR and protein intake in either group. The serum concentration of albumin at the 4 th wk of life was $25.7 \pm 0.7$ and $25.2 \pm 0.7 \mathrm{~g} / \mathrm{L}$, and at the 7 th wk of life it was $27.0 \pm 1.2$ and $27.5 \pm 0.9 \mathrm{~g} / \mathrm{L}$ in the treated and untreated infants, respectively $(p>0.05)$. There were no associations between the serum concentrations of TfR and albumin in either group.
The serum concentrations of $\mathrm{TfR}$ of the three $\mathrm{rHuEPO}$ treated infants who received antibiotics differed from the others only at the $3 \mathrm{rd}$ wk of life $(6.4 \pm 1.4$ versus $3.0 \pm$ $0.2 \mathrm{mg} / \mathrm{L}, p=0.0001$ ). Correspondingly, the serum concentrations of TfR of the 10 infants who had antibiotic treatment and the other untreated infants were similar.

We observed no adverse effects during rHuEPO treatment. No evidence of hypertension was obtained, despite frequent recordings of blood pressure. The mean systolic and diastolic pressures were $64 \pm 1$ and $39 \pm 1 \mathrm{~mm} \mathrm{Hg}$ before, and $63 \pm 1$ and $39 \pm 1 \mathrm{~mm} \mathrm{Hg} \mathrm{2-8} \mathrm{h}$ after the injection. During the treatment period, the lowest individual absolute granulocyte counts were $414 / \mathrm{mm}^{3}$ and $1296 / \mathrm{mm}^{3}$ in the treated and untreated infants, respectively, and the mean absolute granulocyte counts were $3224 \pm 309 / \mathrm{mm}^{3}$ and $3091 \pm 389 / \mathrm{mm}^{3}(p=0.8)$ in the treated and untreated infants, respectively.

\section{DISCUSSION}

The study provided evidence for the efficacy of rHuEPO in stimulating erythropoiesis and reducing the requirement of transfusions for anemia of prematurity. The rHuEPOtreated infants produced about $1 \mathrm{~mL}$ of red cells per $\mathrm{kg}$ per $\mathrm{d}$ more than the untreated infants. We observed no adverse effects among the 21 rHuEPO-treated infants; blood pressures and granulocyte counts were watched especially closely. Nevertheless, we emphasize that the risk of adverse effects is not yet known; so far there have been only two other reports of 11 and 10 VLBW infants treated with doses similar to or exceeding our dose of rHuEPO $(5,7)$.

The serum concentration of TfR in these rHuEPOtreated VLBW infants increased gradually to values several-fold higher than those in the untreated infants. Even the relatively high dose of $6 \mathrm{mg} / \mathrm{kg} / \mathrm{d}$ of iron may still be insufficient and may limit the rate of erythropoiesis when a dose of rHuEPO as large as $900 \mathrm{IU} / \mathrm{kg} / \mathrm{wk}$ is given. This possibility was supported by the cumulative increase in serum TfR concentration during and at $3 \mathrm{wk}$ after discontinuation of the treatment and by the lower serum ferritin values in the treated infants.

An alternative explanation for the elevated TfR concentration during the treatment is that the rate of erythropoiesis is higher than expected from the pattern of $\mathrm{Hb}$ concentration $(9,11)$. If this is the case, rHuEPO-induced erythropoiesis in VLBW infants could be inefficient or associated with some other type of hemolysis. In fact, the association between the serum concentration of $T f R$ and the reticulocyte count disappeared when the infants were treated with rHuEPO (Fig. 2). There was no association between the serum concentration of TfR and total circulating erythrocyte volume in either group. The usefulness of TfR as an early indicator of a therapeutic response to rHuEPO treatment needs further study.

We calculated that the absorption of extra iron in the treated infants should be at least $14 \%$ of the orally administered iron. The mechanism of enhanced iron absorption may be related to the rHuEPO medication (21). 
Even if the estimate is subject to potential errors because of individual blood losses or hemolysis, the amount of extra iron needed because of rHuEPO treatment is nonetheless substantial and unlikely to be obtained completely by the stimulated absorption.

Additional evidence of protein deficiency was not produced by the rHuEPO therapy. This might have been anticipated because of the increased production of red blood cells in the treated infants at an age when marginal protein lack is common (22).

There was a difference in birth weight between the two groups $(p=0.008)$. This is unlikely to have been the cause of the observed difference in the TfR concentration, for there were correlations between the TfR concentrations and birth weights only at the 3rd and 9th wk of life in the treated infants and no correlations in the untreated infants.

The VLBW infants who were given large doses of rHuEPO and iron had a marked rise in serum TfR concentration and a small decline in serum ferritin concentration. Potential iron deficiency as an explanation for these events should be investigated.

Acknowledgment. The authors thank Dr. James D. Cook, Kansas University Medical Center, Kansas City, KS, for supplying the monoclonal antibodies and purified TfR for the immunofluorometric assay.

\section{REFERENCES}

1. Halperin DS, Wacker P, Lacourt G, Felix M, Babel JF, Aapro M, Wyss $M$ 1990 Effects of recombinant human erythropoietin in infants with the anemia of prematurity: a pilot study. J Pediatr 116:779-786

2. Shannon KM, Mentzer WC, Abels RI, Wertz M, Thayer-Moriyama J, Li WY, Thompson D, Decelle S, Phibbs RH 1991 Enhancement of erythropoiesis by recombinant human erythropoietin in low birth weight infants: a pilot study. J Pediatr 120:586-592

3. Obladen M, Maier R, Segerer H, Grauel EL, Holland BM, Stewart G, Jorch $G$, Rabe H, Linderkamp O, Hoffmann HG, Houghton F, Herrmann Z,
Scigalla P, Wardrop C 1991 Efficacy and safety of recombinant human erythropoietin to prevent the anaemias of prematurity. Contrib Nephrol 88:314-326

4. Ohls RK, Christensen RD 1991 Recombinant erythropoietin compared with erythrocyte transfusion in the treatment of anemia of prematurity. J Pediatr 119:781-788

5. Carnielli V, Montini G, Da Riol R, Dall'Amico R, Cantarutti F 1992 Effect of high doses of human recombinant erythropoietin on the need for blood transfusions in preterm infants. J Pediatr 121:98-102

6. Emmerson AJB, Coles HJ, Stern CMM, Pearson TC 1993 Double blind trial of recombinant human erythropoietin in preterm infants. Arch Dis Child 68:291-296

7. Messer J, Haddad J, Donato L, Astruc D, Matis J 1993 Early treatment of premature infants with recombinant human erythropoietin. Pediatrics 92:519523

8. Kivivuori SM, Järvenpää AL, Salmenperä L, Viinikka L, Siimes MA 1994 Erythropoiesis of very low-birth-weight infants dependent on prenatal growth rate and protein status. Acta Paediatr 83:13-18

9. Kohgo Y, Niitsu Y, Kondo H, Kato J, Tsushima N, Sasaki K, Hirayama M, Numata T, Nishisato T, Urushizaki I 1987 Serum transferrin receptor as a new index of erythropoiesis. Blood 70:1955-1958

10. Flowers CH, Skikne BS, Covell AM, Cook JD 1989 The clinical measurement of serum transferrin receptor. J Lab Clin Med 114:386-377

11. Huebers HA, Beguin Y, Pootrakul P, Einspahr D, Finch CA 1990 Intact transferrin receptors in human plasma and their relation to erythropoiesis. Blood 75:102-107

12. Skikne BS, Flowers $\mathrm{CH}$, Cook JD 1990 Serum transferrin receptor: a quantitative measure of tissue iron deficiency. Blood 75:1870-1876

13. Kivivuori SM, Anttila R, Viinikka L, Pesonen K, Siimes MA 1993 Serum transferrin receptor for the assessment of iron status in healthy prepubertal and early pubertal boys. Pediatr Res 34:297-299

14. Beguin Y, Clemons GK, Pootrakul P, Fillet G 1993 Quantitative assessment of erythropoiesis and functional classification of anemia based on measurements of serum transferrin receptor and erythropoietin. Blood 81:1067-1076

15. Ferguson BJ, Skikne BS, Simpson KM, Baynes RD, Cook JD 1992 Serum transferrin receptor distinguishes the anemia of chronic disease from iron deficiency anemia. J Lab Clin Med 119:385-390

16. Siimes MA, Addiego JE, Dallman PR 1974 Ferritin in serum: diagnosis of iron deficiency and iron overload in infants and children. Blood 43:581-590

17. Pihkala J, Hakala T, Voutilainen P, Raivio K 1989 (Characteristics of recent fetal growth curves in Finland). Uudet suomalaiset sikiön kasvukäyrät. Duodecim 105:1540-1546

18. Siimes MA, Järvenpää AL 1982 Prevention of anemia and iron deficiency in very low-birth-weight infants. J Pediatr 101:277-280

19. Green R, Charlton R, Seftel H, Bothwell T, Mayet F, Adams B, Finch C, Layrisse M 1968 Body iron excretion in man. Am J Med 45:336-353

20. Lundström U, Siimes MA, Dallman PR 1977 At what age does iron supplementation become necessary in low-birth-weight infants? J Pediatr 91:878-883

21. Skikne BS, Cook JD 1992 Effect of enhanced erythropoiesis on iron absorption. J Lab Clin Med 120:746-751

22. Rönnholm KAR, Siimes MA 1985 Haemoglobin concentration depends on protein intake in small preterm infants fed human milk. Arch Dis Child 60:99-104 